\title{
Fatty acid composition of beef cattle finished on tropical pasture and supplemented with crude glycerin
}

\section{Composição em ácidos graxos da carne de bovinos terminados a pasto e suplementados com glicerina bruta}

\author{
Evani Souza de Oliveira Strada ${ }^{1}$; Robério Rodrigues Silva²; Gleidson Giordano \\ Pinto de Carvalho ${ }^{3}$; Larissa Pires Barbosa ${ }^{1}$; Ivanor Nunes do Prado ${ }^{4}$; Fabiana

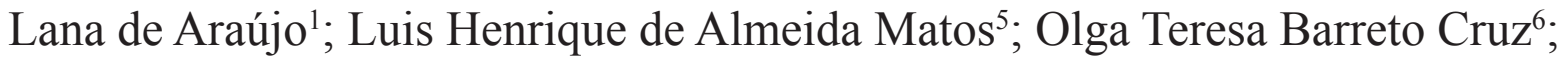 \\ Dorgival Morais de Lima Júnior ${ }^{7 *}$
}

\begin{abstract}
The aim of this study was to evaluate the effect of crude glycerin supplementation on the chemical composition and fatty acid profile of the muscle of cattle grazing on Urochloa decumbens. Thirty-five crossbreed bulls, with an average initial body weight of $428.0 \pm 32.11 \mathrm{~kg}$, were supplemented with dry matter corresponding to $1 \%$ body weight for 74 days on pasture and distributed to five treatments $(0,3$, 6,9 and $12 \%$ low purity glycerin in the total dry matter of the supplement) in a completely randomised design. After 74 days, the animals were slaughtered, and the longissimus dorsi muscle was sampled and frozen for meat composition analysis. The addition of glycerin did not affect the mean moisture (73.6 $\pm 0.3 \%)$, protein $(22.8 \pm 0.4 \%)$, total lipid $(1.1 \pm 0.1 \%)$ and ash $(1.0 \pm 0.04 \%)$ contents of the animal muscle. However, there was an increasing linear effect $(\mathrm{P}<0.05)$ on the contents of trans-vaccenic acid (increase of $175 \%$ in relation to the control) and conjugated linoleic acid (CLA) (25\% increase in relation to the control). We observed an increasing linear pattern in monounsaturated fatty acid levels ( 39.8 to $44.5 \%$ ) and a decreasing linear pattern in polyunsaturated fatty acid content (13.5 to $9.5 \%$ ). The inclusion of crude glycerin promoted a linear decreasing pattern for $\omega-3$ fatty acids. Thus, the inclusion of crude glycerin in the supplement of beef cattle affects the fatty acid composition of the meat. The use of this byproduct promotes desirable changes in the chemical composition of fatty acids, increasing the levels of conjugated linoleic fatty acids (18: 2 c9 t11) and monounsaturated fatty acids.
\end{abstract}

Key words: Biodiesel. Glycerol. Meat quality. Supplementation.

\section{Resumo}

Objetivou-se avaliar o efeito da inclusão de glicerina bruta no suplemento sobre a composição química e o perfil de ácidos graxos do músculo de bovinos terminados em pastagem de Urochloa decumbens. Para

\footnotetext{
1 Profs. Drs., Universidade Federal do Recôncavo da Bahia, UFRB, Cruz das Almas, BA, Brasil. E-mail: evanisos@cdlmma.com. br; larissa@ufrb.edu.br; fabianalana@ufrb.edu.br

2 Prof. Dr., Universidade Estadual do Sudoeste da Bahia, UESB, Itapetinga, BA, Brasil. E-mail: rrsilva.uesb@hotmail.com

3 Prof. Dr., Universidade Federal da Bahia, UFBA, Salvador, BA, Brasil. E-mail: gleidsongiordano@ufba.br

4 Prof. Dr., Universidade Estadual de Maringá, UEM, Maringá, PR, Brasil. E-mail: inprado@uem.br

5 M.e em Zootecnia, Discente do Curso de Doutorado do Programa de Pós-Graduação em Zootecnia, UFBA, Salvador, BA, Brasil. E-mail: luis.matos@yahoo.com.br

6 M.e em Zootecnia, Discente do Curso de Doutorado do Programa de Pós-Graduação em Ciências Agrárias, Universidad del Tolima, UT, Tolima, Colômbia. E-mail: olgatbarreto@misena.edu.co

7 Prof. Dr., Universidade Federal de Alagoas, UFAL, Arapiraca, AL, Brasil. E-mail: juniorzootec@yahoo.com.br

* Author for correspondence
} 
isso foram utilizados 35 touros azebuados, com peso inicial médio de 428,0 $\pm 32,11 \mathrm{~kg}$, suplementados com $1 \%$ do peso corporal, por 74 dias em pastagem e distribuídos em cinco tratamentos $(0,3,6,9$ e $12 \%$ de glicerina de baixa pureza na matéria seca total do suplemento) em delineamento inteiramente casualizado. Após 74 dias os animais foram abatidos, o músculo Longissimus dorsi foi amostrado e congelado para análise de composição da carne. A adição de glicerina no suplemento não afetou ( $\mathrm{P}>0,05)$ os teores médios de umidade $(73,6 \% \pm 0,3)$, proteína $(22,8 \% \pm 0,4)$, lipídeos totais $(1,1 \% \pm 0,1)$ e cinzas $(1,0 \% \pm 0,04)$ do músculo dos animais. Todavia, observou-se efeito linear crescente $(\mathrm{P}<0,05)$ para os teores de ácido trans-vacênico (acréscimo de 175\% em relação ao controle) e ácido linoleico conjugado (CLA) (acréscimo de $25 \%$ em relação ao controle). Observou-se comportamento linear crescente para os teores de ácidos graxos monoinsaturados (39,8 para 44,5\%) e linear decrescente para os teores de ácidos graxos poli-insaturados (13,5\% para 9,5\%). A inclusão da glicerina bruta promoveu comportamento linear decrescente para os ácidos graxos da série $\omega-3$. Assim, a inclusão de glicerina bruta no suplemento afeta a composição em ácidos graxos da carne de bovinos terminados a pasto. $\mathrm{O}$ uso desse coproduto promove alterações desejáveis na composição química em ácidos graxos, aumentando os teores de ácidos graxos linoleico conjugado (18:2 c9 t11) e ácidos graxos monoinsaturados.

Palavras-chave: Biodiesel. Glicerol. Qualidade de carne. Suplementação.

Supplementing finishing cattle on pasture promotes a regular meat supply throughout the year and a faster return on invested capital, mainly due to the reduction of slaughter age. In addition, animals supplemented on pasture present greater weight gain and heavier carcasses. However, supplementation is still considered an expensive practice due to the high cost of the main concentrate ingredients, such as corn and soybean meal.

The use of alternative ingredients, such as agricultural waste, reduces the cost of supplementation and reduces the organic amounts deposited into the environment. In this scenario, biodiesel byproducts - renewable fuel produced by fat esterification - are a prominent alternative ingredient (BESERRA et al., 2016). Among them, crude glycerin, whose main components are glycerol and non-esterified fatty acids, has been identified as an alternative energetic ingredient for ruminants (BOTINI et al., 2015; D'AUREA et al., 2017).

In the rumen, glycerol is fermented into short chain fatty acids, mainly propionate (VAN CLEEF et al., 2015). This organic acid is converted into glucose in the liver of ruminants, generating elevated insulin levels in the blood of these animals. Insulin has anabolic effects and stimulates the synthesis and deposition of fat and protein in animal tissues.

With respect to fat deposition in ruminants, lipids deposited in the muscle are derived from ruminal organic acids or dietary fat. The deposited short and medium chain fatty acids (C10: 0 to C16: 0 ) have acetate as their main precursor, but propionate seems to be indirectly involved in the deposition of intramuscular fat (NAFIKOV; BEITZ, 2007). The same authors observed that, for long chain fatty acids (above C18:0), there seems to be direct fat deposition in the muscle from dietary lipids. In this context, it is important to consider that the pre-gastric fermentation of ruminants extensively modifies the lipid sources offered to the animals.

The inclusion of crude glycerin promotes desirable changes in the fatty acid composition of meat in feedlot cattle (FAVARO et al., 2016). However, few studies have evaluated the effect of glycerin on the composition of fatty acids in grazing beef cattle. Thus, the aim of this study was to evaluate the effect of crude glycerin on the fatty acid composition of grazing cattle muscle.

The project was approved by the Animal Use Ethics Committee (CEUA) of the State University Southwestern Bahia through protocol CEUA 17/2012. The experiment was conducted at the Cruz das Almas campus of the Federal University of Recôncavo Bahiano, Brazil. Cruz das Almas (BA) has an average temperature of $23.0{ }^{\circ} \mathrm{C}$, a relative humidity of $81 \%$ and an average annual rainfall of $1136 \mathrm{~mm}$. 
The experiment was conducted in five pickets with an area of approximately 7 hectares each, totaling an area of 35 hectares (ha) of Urochloa decumbens. The experiment lasted 88 days, with 14 days for the animals to adapt to the management and the experimental diets and 74 days for data collection. Thirty-five male, non-castrated crossbreed bulls with an average initial body weight of $428.0 \pm$ $32.11 \mathrm{~kg}$ and supplemented with dry matter at $1.0 \%$ body weight $(\mathrm{BW})$ were fed diets with increasing levels of crude glycerin, distributed in a completely randomised design with five treatments and seven replicates. Supplements contained 0, 3, 6, 9 and $12 \%$ inclusion of low purity glycerin in the total diet and were formulated according to the NRC (2000) to meet maintenance requirements and lead to an average daily gain (ADG) of $1.2 \mathrm{~kg} /$ day (Table 1). Supplements were provided in troughs, with $20 \mathrm{~cm}$ allotted for each animal, in a single daily meal at 11:00 AM.

Table 1. Percent composition of supplements based on dry matter and chemical composition, and fatty acid profile of supplements and pasture.

\begin{tabular}{|c|c|c|c|c|c|c|}
\hline & \multirow[b]{2}{*}{ Urochloa decumbens } & \multicolumn{5}{|c|}{ Low-purity glycerin levels (\%DM) } \\
\hline & & 0 & 3 & 6 & 9 & 12 \\
\hline \multicolumn{7}{|l|}{ Ingredients $(\%)$} \\
\hline Whole shelled corn & & 79,35 & 70,91 & 62,30 & 53,53 & 44,58 \\
\hline Soybean meal & & 17,30 & 18,95 & 20,64 & 22,35 & 24,10 \\
\hline Crude glycerin & & - & 6.76 & 13.65 & 20.68 & 27.85 \\
\hline Urea & & 1.85 & 1.87 & 1.88 & 1.90 & 1.92 \\
\hline Mineral mix ${ }^{1}$ & & 0.99 & 1.00 & 1.00 & 1.02 & 1.02 \\
\hline Limestone & & 0.51 & 0.51 & 0.52 & 0.52 & 0.53 \\
\hline \multicolumn{7}{|l|}{ Components } \\
\hline Dry matter (\%) & 31.60 & 85.81 & 87.52 & 86.00 & 84.49 & 85.36 \\
\hline Mineral matter (\%) & 8.30 & 3.06 & 3.30 & 3.53 & 3.49 & 3.81 \\
\hline Organic matter (\%) & 91.70 & 96.94 & 96.70 & 96.47 & 96.51 & 96.19 \\
\hline Crude Protein (\%) & 13.10 & 24.39 & 24.69 & 24.29 & 22.33 & 23.54 \\
\hline Ether extract (\%) & 2.98 & 3.13 & 5.39 & 6.23 & 6.62 & 8.56 \\
\hline Neutral detergent fiber (\%) & 69.61 & 25.49 & 25.01 & 25.25 & 18.98 & 18.51 \\
\hline NDFap $^{2}(\%)$ & 62.32 & 13.64 & 7.41 & 5.87 & 6.33 & 4.28 \\
\hline Total carbohydrates $(\%)$ & 75.55 & 69.42 & 66.62 & 65.95 & 67.56 & 64.09 \\
\hline $\mathrm{NFCap}^{3}(\%)$ & 5.94 & 43.93 & 41.61 & 40.70 & 48.58 & 45.58 \\
\hline $\operatorname{TDN}^{4}(\%)$ & 56.87 & 89.00 & 85.84 & 84.87 & 92.13 & 92.66 \\
\hline $\mathrm{CME}^{5}(\mathrm{Mcal}$ of ME $/ \mathrm{kg}$ of DM) & 3.88 & 3.92 & 3.78 & 3.74 & 4.06 & 4.09 \\
\hline \multicolumn{7}{|l|}{ Fatty acids composition $(\%)$} \\
\hline C16:0 (Palmitic) & 37.7 & 14.8 & 13.2 & 14.0 & 15.0 & 15.8 \\
\hline C18:0 (Stearic) & 2.3 & 2.7 & 3.3 & 2.6 & 2.6 & 2.6 \\
\hline C18:1 $\omega-9 c$ (Oleic) & 0.4 & 29.5 & 29.3 & 25.4 & 22.3 & 21.0 \\
\hline C18:1 $\omega-7 t$ (Octadecanoic) & 0.4 & 0.6 & 0.8 & 0.8 & 0.7 & 0.1 \\
\hline C18:2 $\omega-6$ (Linoleic) & 14.5 & 49.2 & 50.2 & 53.9 & 56.4 & 56.9 \\
\hline C18:3 $\omega-6$ (Linolenic) & 43.7 & 1.9 & 2.0 & 2.3 & 2.3 & 2.4 \\
\hline
\end{tabular}


continuation

\begin{tabular}{lcccccc} 
SFA & 36.4 & 19.1 & 17.6 & 17.3 & 18.0 & 19.2 \\
MUFA & 5.20 & 30.1 & 30.3 & 26.4 & 23.2 & 21.5 \\
PUFA & 58.3 & 50.8 & 52.1 & 56.2 & 58.8 & 59.3 \\
$\omega-6 / \omega-3$ & 0.3 & 27.4 & 24.9 & 23.8 & 24.3 & 24.1 \\
\hline
\end{tabular}

${ }^{1}$ Composition in $100 \mathrm{~g}$ : Sodium chloride $(\mathrm{NaCl})$ - 47.15g; Dicalcium phosphate - $50 \mathrm{~g}$; Zinc sulphate - $1.5 \mathrm{~g}$; Copper sulphate - $0.75 \mathrm{~g}$; Cobalt sulfate - $0.05 \mathrm{~g}$; Potassium iodide - $0.05 \mathrm{~g}$; Magnesium sulphate - $0.5 \mathrm{~g} .{ }^{2}$ Neutral detergent fiber corrected for ash and protein; ${ }^{3}$ Non-fibrous carbohydrates corrected for ash and protein; ${ }^{4}$ Total digestible nutrients; ${ }^{5}$ Concentration of metabolizable energy.

Glycerol was analysed by Karl Fischer's method; it presented the following physicochemical composition in terms of natural matter percentage: $43.9 \%$ glycerol, $6.0 \%$ methanol, $33.6 \%$ total fatty acids, $9.0 \%$ water and $7.3 \%$ mineral matter. Total fatty acids had the following distribution: $20.2 \%$ C16: 0; 5.13\% C18: 0; $22.3 \%$ C18: $1 \omega-9$ and 45.7\% C18: $2 \omega-6$.

Every seven days, the animals and diets rotated through the pickets to reduce the influence of biomass variation between pickets and to eliminate any possible environmental effects on the treatments. To estimate the availability of total dry matter, the pickets were evaluated every 28 days, during which time samples were taken by cutting a $0.25 \mathrm{~m}^{2}$ square of grass at ground level.

The following analyses were performed: dry matter (DM), mineral matter (MM), crude protein (CP), ethereal extract (EE), neutral detergent fibre (NDF), neutral detergent fibre corrected for ash and protein (NDFap), total carbohydrates (TCHO) and non-fibrous carbohydrates corrected for ash and protein (NFCap); these were performed according to the techniques described by the INCT-CA (2012). The total digestible nutrients (TDN) were calculated according to Weiss et al. (1992).

After 84 days, the animals were slaughtered according to the usual routine of the commercial slaughterhouse. Immediately after slaughter, the carcasses were identified and cooled at $2{ }^{\circ} \mathrm{C}$ for 24 hours. After cooling, a section from the longissimus dorsi muscle, between the $11^{\text {th }}$ and $13^{\text {th }}$ ribs of each left half-carcass, was taken and frozen for further analysis. The samples were thawed at room temperature with subsequent removal of the subcutaneous fat, and then ground to determine the DM, MM and CP contents, according to the methodology described by INCT-CA (2012). The methodology proposed by Bligh and Dyer (1959) was used to extract the total lipids from the meat.

The preparation of fatty acid methyl esters was performed according to method 5509 of the ISO (1978). Chromatographic analysis was conducted using a Varian gas chromatograph, model CP-3380, equipped with a flame ionisation detector, injector with / without sample partitioning and a CP-7420 fused silica capillary column (100\% cyanopropyl bound, dimensions: $100 \mathrm{~m}, 0.25 \mathrm{~mm}$ d.s and 0.25 $\mu \mathrm{m}$ stationary phase). The injector and detector temperatures were maintained at $220{ }^{\circ} \mathrm{C}$ and 240 ${ }^{\circ} \mathrm{C}$, respectively. Gas flow rates were $1.4 \mathrm{~mL} / \mathrm{min}$ for the entrainment gas $(\mathrm{H} 2), 30 \mathrm{~mL} / \mathrm{min}$ for the auxiliary gas (N2), and $30 \mathrm{~mL} / \mathrm{min}$ and $300 \mathrm{~mL}$ / min for the gas (H2) and the flame synthetic air, respectively. The sample divider was $1 / 80$. The operating parameters were: column temperature of $165^{\circ} \mathrm{C}$ for $12 \mathrm{~min}$, then raised to $180{ }^{\circ} \mathrm{C}$ at a rate of $40{ }^{\circ} \mathrm{C} / \mathrm{min}$, remaining at this temperature for $15 \mathrm{~min}$ and then raised to $240{ }^{\circ} \mathrm{C}$ at a rate of $15{ }^{\circ} \mathrm{C}$ / $\min$ for $18.62 \mathrm{~min}$, which resulted in a 50-minute run. Peak areas were determined using the software Workstation 5.0 (Varian). The quantification of fatty acids was performed after area normalisation. Peaks were identified by comparing the retention times of Sigma fatty acid methyl ester standards (USA) and after checking the equivalent chain length. 
Data were evaluated using an analysis of variance and regression. Statistical models were chosen according to the significance of the regression coefficients at $5 \%$ probability.

The inclusion of crude glycerin did not affect $(\mathrm{P}$ $>0.05)$ the mean moisture $(73.6 \pm 0.3 \%)$, protein $(22.8 \pm 0.4 \%)$, total lipid $(1.1 \pm 0.1 \%)$ and ash $(1.0 \pm 0.04 \%)$ content of the longissimus dorsi of grazing cattle (Table 2). The amount of protein in the bovine muscle was quite stable amongst the same genetic group at the same physiological stage; the same cannot be said about lipids. In this case, the diet energy level has a marked influence on the degree of fattening (HOMEM JUNIOR et al., 2016; MANNI et al., 2018). There was a small variation in the energy content of the supplements (3.92 to $4.09 \mathrm{Mcal}$ of ME / $\mathrm{kg}$ of DM) and, therefore, there was not enough to affect the lipid concentration in the bovine meat.

Table 2. Chemical composition of Longissimus dorsi muscle of cattle supplemented on Urochloa decumbens pasture with low purity glycerin

\begin{tabular}{|c|c|c|c|c|c|c|c|c|}
\hline \multirow{2}{*}{ Contents $(\%)$} & \multicolumn{5}{|c|}{ Low-purity glycerin levels (\%DM) } & \multirow[t]{2}{*}{ MSE } & \multicolumn{2}{|c|}{ P Value } \\
\hline & 0 & 3 & 6 & 9 & 12 & & $\mathrm{~L}$ & Q \\
\hline Moisture & 73.5 & 74.2 & 73.5 & 73.6 & 73.4 & 0.21 & 0.47 & 0.44 \\
\hline Crude protein & 23.4 & 22.5 & 22.8 & 22.7 & 22.4 & 0.28 & 0.18 & 0.50 \\
\hline Total lipid & 1.1 & 0.9 & 1.3 & 1.1 & 1.2 & 0.10 & 0.20 & 0.18 \\
\hline Mineral matter & 1.0 & 1.0 & 1.0 & 1.1 & 1.0 & 0.01 & 0.82 & 0.24 \\
\hline
\end{tabular}

$\mathrm{MSE}=$ mean standard error; $\mathrm{L}, \mathrm{Q}=$ order of linear and quadratic effects for the inclusion of low-purity glycerin in the diet.

The inclusion of crude glycerin increased $(\mathrm{P}$ $<0.05)$ the levels of C21: 0 fatty acid in bovine muscle (Table 3 ). In ruminant tissues, the synthesis of long chain fatty acids (20-22 carbons) occurs from the enzymatic elongation and desaturation of dietary linoleic and linolenic (C18) acids (WOODS; FEARON, 2009). Thus, the increase in linoleic and linolenic acid content in the supplement provided a greater availability of precursors for tissue elongases, culminating in a higher $\mathrm{C} 21$ : 0 content in the muscle.

There was an increasing linear pattern in the

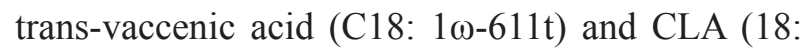
2-c9-t11) levels in bovine muscle. This effect can be attributed to the elevated level of crude glycerol in the diet, which is rich in linoleic acid (C18: 2 $\omega-6)$. This fatty acid undergoes successive additions of hydrogen in the bovine rumen until its complete saturation in stearic acid (C18: 0) (HUR et al., 2017). However, depending on the abundance, it is possible to absorb hydrogenation intermediates (such as
C18: $1 \omega-6$ 11t and C18: 2-c9-t11) in the intestine of ruminants, with their subsequent deposition into adipose tissue. It is also important to observe the effect of $\Delta-9$ desaturase in the conversion of trans-

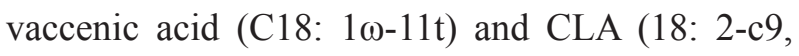
t11) in the adipose tissue of ruminants, as observed by Carvalho et al. (2015) in sheep.

The concentrations of glycerol, trans-vaccenic acid $(5.54 \%)$ and CLA $(0.10 \%)$ observed in the present study are much higher than those reported by Eiras et al. (2014) in feedlot cattle fed 18\% glycerin. It can be inferred that, due to its richness in linolenic acid (43.7\% C18: $3 \omega-6)$, forage increases the amount of hydrogenation intermediates for absorption in the small intestine of ruminants and increases their deposition in bovine muscle (CATRILEO et al., 2014).

In animal tissues, linolenic acid (C18: $3 \omega-3)$ is enzymatically converted into three important fatty acids: eicosapentaenoic (EPA) (C20: 5 
$\omega-3)$, docosapentaenoic acid (DPA) (C22: $5 \omega-3)$ and docosahexaenoic acid (DHA) (C22: 6 w-3) (PALMQUIST; MATTOS, 2006). EPA and DHA, as well as linolenic acid, had reduced concentrations in the muscle of cattle with the inclusion of glycerin supplementation; it is likely that the increase of linoleic acid in the supplement (from 49.2 to $56.9 \%$ of total lipids) promoted this reduction. Linoleic acid is from the $\omega-6$ series and competes with the fatty acids from the $\omega-3$ series - linolenic acid and its derivatives - by the same double bond insertion enzymes (D-6-desaturase) (HARNACK et al., 2009). In this context, the elevation of dietary linoleic acid and an increase of $\omega-6$ intermediates, such as trans-vaccenic acid, may have led to reduced insertions of D-6-desaturase promoted instaurations in $\omega-3$ fatty acids such as EPA and DHA.

The rationale of competition for fatty acid enzymes in the $\omega-6$ and $\omega-3$ series is strengthened by our findings. In addition to an increase in transvaccenic acid, we also observed a negative linear pattern $(\mathrm{P}<0.05)$ in the lipid content of $\omega-3$ series lipids and a positive linear pattern $(\mathrm{P}<0.05)$ in the $\omega-6: \omega-3$ ratio in the muscle of cattle with glycerin supplementation.

Table 3. Fatty acid composition of Longissimus dorsi muscle of cattle supplemented on Urochloa decumbens pasture with low purity glycerin

\begin{tabular}{|c|c|c|c|c|c|c|c|c|}
\hline \multirow{2}{*}{$\begin{array}{c}\text { Fatty acids } \\
(\%)\end{array}$} & \multicolumn{5}{|c|}{ Low-purity glycerin levels (\%DM) } & \multirow[t]{2}{*}{ MSE } & \multicolumn{2}{|c|}{ P Value } \\
\hline & 0 & 3 & 6 & 9 & 12 & & $\mathrm{~L}$ & Q \\
\hline C12:0 (lauric) & 0.16 & 0.13 & 0.13 & 0.12 & 0.13 & 0.01 & 0.34 & 0.44 \\
\hline C13:0 (tridecanoic) & 0.13 & 0.16 & 0.11 & 0.11 & 0.11 & 0.01 & 0.11 & 0.61 \\
\hline C14:0 (myristic) & 2.09 & 1.74 & 2.48 & 2.41 & 2.37 & 0.12 & 0.16 & 0.85 \\
\hline C15:0(pentadecanoic) & 0.43 & 0.43 & 0.43 & 0.44 & 0.47 & 0.01 & 0.56 & 0.65 \\
\hline C16:0 (palmitic) & 23.49 & 21.86 & 23.38 & 23.35 & 22.95 & 0.35 & 0.83 & 0.69 \\
\hline C17:0 (margic) & 0.91 & 0.88 & 1.04 & 0.87 & 1.03 & 0.035 & 0.11 & 0.74 \\
\hline C18:0 (stearic) & 17.96 & 17.94 & 19.98 & 16.63 & 17.06 & 0.004 & 0.24 & 0.15 \\
\hline C20:0 (arachidic) & 0.11 & 0.10 & 0.11 & 0.09 & 0.11 & 0.06 & 0.211 & 0.15 \\
\hline C21:0 (heneicosanoic) ${ }^{1}$ & 0.54 & 0.62 & 0.80 & 0.97 & 1.15 & 0.05 & $0.0005^{*}$ & 0.17 \\
\hline C22:0 (behenic) & 0.15 & 0.15 & 0.16 & 0.12 & 0.15 & 0.008 & 0.189 & 0.72 \\
\hline C24:0 (lignoceric) & 0.63 & 0.79 & 0.42 & 0.55 & 0.43 & 0.25 & 0.128 & 0.87 \\
\hline 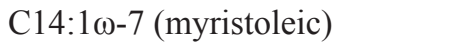 & 0.31 & 0.29 & 0.37 & 0.44 & 0.47 & 0.03 & 0.03 & 0.70 \\
\hline 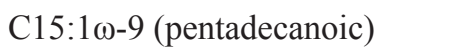 & 0.25 & 0.25 & 0.20 & 0.17 & 0.18 & 0.01 & 0.06 & 0.83 \\
\hline 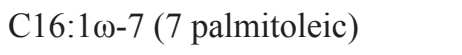 & 0.55 & 0.52 & 0.58 & 0.48 & 0.53 & 0.02 & 0.37 & 0.96 \\
\hline C16:1 $\omega-9$ (9 palmitoleic) & 2.37 & 2.13 & 2.16 & 2.53 & 2.53 & 0.01 & 0.55 & 0.56 \\
\hline C17:1 $\omega-9$ (heptadecanoic) & 0.68 & 0.65 & 0.62 & 0.67 & 0.73 & 0.01 & 0.20 & 0.01 \\
\hline C18:1 $\omega-7$ (7octadecanoic) & 1.15 & 1.14 & 1.00 & 1.10 & 1.11 & 0.02 & 0.57 & 0.20 \\
\hline 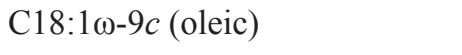 & 32.47 & 31.01 & 32.25 & 30.99 & 33.36 & 0.05 & 0.50 & 0.10 \\
\hline $\mathrm{C} 18: 1 \omega-611 t(\operatorname{trans} \text { vaccenic })^{2}$ & 2.00 & 2.50 & 4.13 & 4.37 & 5.54 & 0.37 & $0.005^{*}$ & 0.96 \\
\hline C 18: $2 \omega-6$ (linoleic) & 8.65 & 9.02 & 5.54 & 9.14 & 6.47 & 0.88 & 0.31 & 0.84 \\
\hline $\mathrm{C} 18: 2 \omega-9 . t-11(\mathrm{CLA})^{3}$ & 0.08 & 0.08 & 0.10 & 0.08 & 0.10 & 0.005 & $0.009^{*}$ & 0.80 \\
\hline C18:3 $\omega-6(\gamma$ linolenic $)$ & 0.14 & 0.13 & 0.14 & 0.14 & 0.15 & 0.87 & 0.52 & 0.32 \\
\hline C18:3 $\omega-3 c(\alpha \text { linolenic })^{4}$ & 1.27 & 1.42 & 0.83 & 1.07 & 0.79 & 0.10 & $0.003^{*}$ & 0.94 \\
\hline
\end{tabular}


continuation

\begin{tabular}{|c|c|c|c|c|c|c|c|c|}
\hline $\mathrm{C} 20: 2 \omega-6$ (eicosadienoic) $^{5}$ & 0.04 & 0.03 & 0.01 & 0.01 & 0.01 & 0.0001 & $0.06^{*}$ & 0.26 \\
\hline C20:4 $\omega-6$ (arachidonic) & 0.29 & 0.27 & 0.17 & 0.23 & 0.17 & 0.009 & 0.06 & 0.58 \\
\hline $\mathrm{C} 20: 3 \omega-3$ (eicosatrienoic) $^{6}$ & 0.14 & 0.15 & 0.11 & 0.11 & 0.09 & 0.0002 & $0.002^{*}$ & 0.66 \\
\hline C20:5 $\omega-3$ (eicosapentaenoic) ${ }^{7}$ & 0.12 & 0.13 & 0.10 & 0.11 & 0.08 & 0.003 & $0.009^{*}$ & 0.60 \\
\hline C22:6 $\omega-3$ (docosahexanoic) & 2.74 & 3.23 & 1.66 & 2.57 & 1.61 & 0.69 & 0.01 & 0.75 \\
\hline $\mathrm{SFA}^{\mathrm{I}}$ & 46.69 & 44.85 & 49.09 & 45.71 & 46.01 & 0.84 & 0.897 & 0.459 \\
\hline MUFA $^{\mathrm{II}}$ & 39.81 & 38.52 & 41.34 & 40.78 & 44.48 & 1.19 & $<0.001^{*}$ & 0.063 \\
\hline PUFA $^{\mathrm{III}}$ & 13.49 & 16.62 & 9.56 & 13.50 & 9.50 & 0.37 & $0.034^{*}$ & 0.586 \\
\hline$\omega-6^{\mathrm{IV}}$ & 9.12 & 11.58 & 6.75 & 9.54 & 6.82 & 0.03 & 0.066 & 0.510 \\
\hline$\omega-3^{v}$ & 4.28 & 4.95 & 2.70 & 3.87 & 2.57 & 0.84 & $0.007^{*}$ & 0.788 \\
\hline PUFA:SFA ${ }^{\mathrm{VI}}$ & 0.29 & 0.37 & 0.19 & 0.30 & 0.20 & 0.06 & 0.080 & 0.654 \\
\hline$\omega-6: \omega-3^{\mathrm{VII}}$ & 2.21 & 2.32 & 2.51 & 2.52 & 2.67 & 0.43 & $<0.001^{*}$ & 0.799 \\
\hline
\end{tabular}

$\mathrm{MSE}=$ mean standard error; $\mathrm{L}, \mathrm{Q}=$ order of linear and quadradic effect of the inclusion of low-purity glycerin in the diet. $1 \hat{\mathrm{Y}}=0,112119 \mathrm{x}+0,00071\left(\mathrm{R}^{2}=0,98\right) ;{ }^{2} \hat{\mathrm{Y}}=0,298741 \mathrm{x}+1,9201\left(\mathrm{R}^{2}=0,96\right) ;{ }^{3} \hat{\mathrm{Y}}=0,0014956 \mathrm{x}+0,0830579\left(\mathrm{R}^{2}=0,49\right) ;{ }^{4} \hat{\mathrm{Y}}=$ $0,043748 \mathrm{x}+1,34122\left(\mathrm{R}^{2}=0,57\right) ;{ }^{5} \hat{\mathrm{Y}}=-0,0048129 \mathrm{x}+0,151021\left(\mathrm{R}^{2}=0,82\right) ;{ }^{6} \hat{\mathrm{Y}}=-0,00423 \mathrm{x}+0,136295\left(\mathrm{R}^{2}=0,67\right) ;{ }^{7} \hat{\mathrm{Y}}=$ $-0,09731 \mathrm{x}+2,95115\left(\mathrm{R}^{2}=0,43\right) ;{ }^{\mathrm{I}}$ saturated fatty acids; ${ }^{\text {II }}$ monounsaturated fatty acids; ${ }^{\text {III }}$ polyunsaturated fatty acids ; ;V $\omega-6$ fatty acids; ${ }^{\mathrm{V}} \omega$ - 3 fatty acids; ${ }^{\mathrm{VI}} P U F A$ : SFA ratio ; ${ }^{\mathrm{VII}} \omega-6: \omega-3$ ratio; ${ }^{\mathrm{II}} \hat{\mathrm{Y}}=0,3866 \mathrm{x}+38,6714\left(\mathrm{R}^{2}=0,68\right) ;{ }^{\text {"III }} \hat{\mathrm{Y}}=-0,370036 \mathrm{x}+14,7565$ $\left(\mathrm{R}^{2}=0,34\right) ;{ }^{\mathrm{V}} \hat{\mathrm{Y}}=-0,150105 \mathrm{x}+4,57968\left(\mathrm{R}^{2}=0,48\right) ;{ }^{\mathrm{VII}} \hat{\mathrm{Y}}=0,0371 \mathrm{x}+2,22845\left(\mathrm{R}^{2}=0,95\right)$.

The inclusion of glycerin in the diet did not influence $(\mathrm{P}>0.05)$ the percentage of total saturated fatty acids (SFA). However, total monounsaturated fatty acid content (MUFA) linearly increased (P $<0.05$ ) with the inclusion of glycerin in the diet. The content of SFA was not modified, since the inclusion of glycerin did not influence the muscle myristic (C14: 0), palmitic (C16: 0) and stearic (C18: 0) contents, which together represent 93.5\% of the analysed SFA. However, the MUFA content in bovine meat showed a linear pattern $(\mathrm{P}<0.05)$, possibly due to the increase in trans-vaccenic acid concentrations (C18: 1 $\omega-11 \mathrm{t})$, which also increased linearly. The content of polyunsaturated fatty acids (PUFA) in the bovine muscle showed a linearly decreasing pattern $(\mathrm{P}<0.05)$ with glycerin supplementation. This effect is possibly due to ruminal hydrogenation and a reduction of $\omega-3$ series polyunsaturated acids in animal tissues.

Crude glycerin supplementation affects the fatty acid composition of meat from beef cattle finished on pasture. Despite an increase in the $\omega-6: \omega-3$ ratio, the use of this byproduct promotes desirable changes in the chemical composition of fatty acids, increasing the levels of conjugated linoleic fatty acids (18: 2 c9 t11) and monounsaturated fatty acids. Depending on the byproduct cost and its availability, we recommended the addition of $12 \%$ crude glycerin to the diet of grazing beef cattle to produce meat with a more desirable fatty acid composition.

\section{Acknowledgements}

To UFRB/ Campus of Cruz das Almas, BA, to UESB/Campus of Itapetinga, BA and to FAPESB

\section{References}

BeSERrA, V. A.; CESAR, A. S.; PERES, A. A. C. Adoção da glicerina bruta na dieta animal e seu impacto no produto final. Archivos de Zootecnia, Córdoba, v. 65, n. 250, p. 259-265, 2016.

BLIGH, E. G.; DYER, W. J. A rapid method of total lipid extraction and purification. Canadian Journal of Biochemistry and Physiology, Alberta, v. 37, n. 8, p. 911917, 1959. 
BOTINI, L. A.; MORAES, K. A. K.; MORAES, E. H. B. K.; PINA, D. S.; PAULA, D. C.; HOFFMANN, A.; STINGUEL, H.; SOCREPPA, L. M.; MENESES, D. M. Glicerina bruta em suplementos para bovinos de corte a pasto no período seco. Pesquisa Agropecuária Brasileira, Brasília, v. 50, n. 3, p. 242-249, 2015.

CARVALHO, V. B.; LEITE, R. F.; ALMEIDA, M. T. C.; PASCHOALOTO, J. R.; CARVALHO, E. B.; LANNA, D. P. D.; PEREZ, H. L.; VAN CLEEF, E. H. C. B.; HOMEM JUNIOR, A. C.; EZEQUIEL, J. M. B. Carcass characteristics and meat quality of lambs fed high concentrations of crude glycerin in low-starch diets. Meat Science, Illinois, v. 110, n. 3, p. 285-292, 2015.

CATRILEO,A.; MORALES, R.; ROJAS, C.; CANCINO, D. Beef production from dairy bulls under two different production systems and its effect on the fatty acid profile and beef quality. Chilean Journal of Agricultural Research, Chillán, v. 74, n. 3, p. 366-370, 2014.

D'AUREA, A. P.; EZEQUIEL, J. M. B.; D'AUREA, E. M. O.; SANTOS, V. C.; FÁVARO, V. R.; HOMEM JÚNIOR, A. C.; ALMEIDA, M. T. C.; PEREZ, H. L. Glicerina bruta associada à ureia na terminação de bovinos: consumo, desempenho e características da carne. Arquivo Brasileiro de Medicina Veterinária e Zootecnia, Belo Horizonte, v. 69, n. 1, p. 165-172, 2017.

EIRAS, C. E.; BARBOSA, L. P.; MARQUES, J. A.; ARAÚJO, F. L.; LIMA, B. S.; ZAWADZKI, F.; PEROTTO, D.; PRADO, I. N. Glycerine levels in the diets of crossbred 1 bulls finished in feedlot: animal performance, carcass dressing, feed intake and apparent digestibility. Animal Feed Science and Technology, Madrid, v. 197, n. 3, p. 222-226, 2014.

FAVARO, V. R.; EZEQUIEL, J. M.; ALMEIDA, M. T.; D'AUREA, A. P.; PASCHOALOTO, J. R.; VAN CLEEF, E. H.; CARVALHO, V. B.; JUNQUEIRA, N. B. Carcass traits and meat quality of Nellore cattle fed different non-fiber carbohydrates sources associated with crude glycerin. Animal, Cambridge, v. 10, n. 8, p. 1402-8, 2016.

HARNACK, K.; ANDERSEN, G.; SOMOZA, V. Quantitation of alpha-linolenic acid elongation to eicosapentaenoic and docosahexaenoic acid as affected by the ratio of n6/n3 fatty acids. Nutrition \& Metabolism, London, v. 19, n. 6, p. 8, 2009.

HOMEM JUNIOR, A. C.; CHIQUITELLI NETO, M.; PINHEIRO, R. S. B.; KOURY FILHO, W.; ESTREMOTE, M.; CAMERRO, L. Z.; DONOFRE, A. C.; PROSPERO PUOLI FILHO, J. N. Influence of concentrate levels in diet and body biotypes on productive variables of Guzera beef cattle. Semina: Ciências Agrárias, Londrina, v. 37, n. 6, p. 4305-4312, 2016.
HUR, S. J.; KIM, H. S.; BAHK, Y. Y.; PARK, Y. Overview of conjugated linoleic acid formation and accumulation in animal products. Livestock Science, Foulum, v. 195, n. 5, p. 105-111, 2017.

INSTITUTO NACIONAL DE CIÊNCIA E TECNOLOGIA - CIÊNCIA ANIMAL - INCT-CA. Métodos para análise de alimentos. Visconde do Rio Branco: Suprema, 2012. 214 p.

INTERNATIONAL ORGANIZATION FOR STANDARDIZATION - ISO. Animal and vegetable fats and oils - Preparation of methyl esters of fatty acids (Method ISO 5509). Geneve: ISO, 1978. p.1-6.

MANNI, K.; RINNE, M.; HUUSKONENC, A.; HUHTANEN, P. Effects of contrasting concentrate feeding strategies on meat quality of growing and finishing dairy bulls offered grass silage and barley based diets. Meat Science, Illinois, v. 143, n. 2, p. 184-189, 2018.

NAFIKOV, R. A.; BEITZ, D. C. Carbohydrate and lipid metabolism in farm animals. The Journal of Nutrition, London, v. 137, n. 3, p. 702-705, 2007.

NATIONAL RESEARCH COUNCIL - NRC. Nutrient requirements of dairy cattle. $7^{\text {th }}$ ed. Washington: National Academy Press, 2000. 450 p.

PALMQUIST, D. L.; MATTOS, W. R. S. Metabolismo de lipídeos. In: BERCHIELLI, T. T.; PIRES, A. V.; OLIVEIRA, S. G. (Ed.). Nutrição de ruminates. Jaboticabal: Funep, 2006. 583 p.

VAN CLEEF, E. H. C. B.; ALMEIDA, M. T. C.; PEREZ, H. L.; VAN CLEEF, F. O. S.; SILVA, D. A. V.; EZEQUIEL, J. M. B. Crude glycerin changes ruminal parameters, in vitro green house gas profile, and bacterial fractions of beef cattle. Livestock Science, Foulum, v. 178, n. 6, p. 158-164, 2015.

WEISS, W. P.; CONRAD, H. R.; PIERRE, N. R. St. A theoretically-based model for predicting total digestible nutrient values of forages and concentrates. Animal Feed Science and Technology, Madrid, v. 39, n. 4, p. 95-110, 1992.

WOODS, V. B.; FEARON, A. M. Dietary sources of unsaturated fatty acids for animals and their transfer into meat, milk and eggs: a review. Livestock Science, Foulum, v. 126, n. 1-3, p. 1-20, 2009. 